\title{
Effect of partly replacing dietary concentrate by beet pulp on milk yield and composition in early lactating cows
}

\author{
Z.M. Kowalski ${ }^{1}$, P. Micek, M. Lopuszańska-Rusek and E. Ćwikilewicz \\ Agricultural University of Cracow, \\ Department of Animal Nutrition \\ Al. Mickiewicza 24/28, 30-059 Kraków, Poland
}

\begin{abstract}
The aim of the study was to determine if wet-ensiled (WBP) or molassed dried beet pulp (MBP) could partly replace concentrate mixture in diets for cows in early lactation. Feeding $2.5 \mathrm{~kg}$ (DM) of wet ensiled or molassed beet pulp instead of $2.25 \mathrm{~kg}$ (DM) of concentrate mixture had no effect on dry matter intake, milk yield and composition, or on body condition and blood parameters. Cows fed MBP diets, compared with WBP, had a better energy status, confirmed by serum NEFA and body condition.
\end{abstract}

KEY WORDS: cow, beet pulp, early lactation, yield, blood parameters

\section{INTRODUCTION}

The early lactation cow often develops a negative energy balance and the use of high concentrate diets is the easiest way of increasing energy intake. Because high doses of readily available carbohydrates can cause rumen acidosis (Nocek, 1997), other sources of easily available energy that have a smaller effect on rumen fermentation are needed. The aim of a study was to determine if wet ensiled or molassed dried beet pulp, containing considerable amount of pectins and sucrose, could partly replace concentrate mixture in diets for high yielding cows producing over $30 \mathrm{~kg}$ of milk/day. Using beet pulp is not a new concept, but the molassed pulps studied here are produced in a new technology in which the final product has been sprayed with a fine coating of vegetable oil ( $0.7 \%$ on feed basis; Trident Feeds, British Sugar Overseas, Poland Ltd.).

\footnotetext{
${ }^{1}$ Corresponding author: e-mail: rzkowlas@cyf-kr.edu.pl
} 


\section{MATERIAL AND METHODS}

Thirty Holstein-Friesian cows were selected from a 400-cow commercial herd, blocked by parity, calving date (DIM \pm 37$)$ and previous lactation yield and assigned randomly to one of three treatments: diet with no beet pulp (control), diet containing wet ensiled beet pulp (WBP, 16.2\% of DM) or molassed dried beet pulp (MBP, Trident Feeds). The control diet cows were fed ad libitum with TMR (Table 1) formulated for a daily milk yield of $35 \mathrm{~kg}$ (INRA, 1989). In the WBP and MBP rations $2.25 \mathrm{~kg}$ of concentrate mixture (DM) were replaced by 2.5 $\mathrm{kg}$ of beet pulp DM. The control TMR consisted of (\% of diet DM) maize silage 31.6, lucerne silage 20.1, barley straw 3.6, wet brewery grains 6.7 and concentrate mixture 38. Cows were kept in a tie-stall barn and rations were offered individually once daily at $12.00 \mathrm{~h}$. The experimental period of 6 weeks started after 2 weeks of adaptation to the diets. Once a week the daily milk yield was recorded (milking twice daily). Additionally once a week feed intake was determined on 5 cows in each group. Milk composition was determined by an infrared procedure. The body condition of the animals was also scored (5-point scale; Wildman et al., 1982) at the beginning and end of the experiment. Blood samples (jugular vein) were collected from 5 cows in each group at $12.00 \mathrm{~h}$ on the final day of intake. Serum was analysed for glucose, urea, NEFA and $\beta$-hydroxybutyrate using commercial diagnostic kits. The samples of feeds, TMRs and refusals were chemically analysed using standard methods (AOAC, 1995). The particle size of TMRs was determined using a Penn State Forage and TMR Particle Separator. The results were subjected to one-way analysis of variance and the Scheffe test (SAS, 1996).

\section{RESULTS}

Inclusion of MBP or WBP into a diet had no effect on energy concentration but decreased the protein (PDIN and PDIE) content (Table 1). It also did not

Table 1. Chemical composition of WBP and MBP and nutritive value of the diets, \% DM

\begin{tabular}{lcrrcc}
\hline \multirow{2}{*}{ Item } & \multirow{2}{*}{ WBP } & \multirow{2}{*}{ MBP } & \multicolumn{3}{c}{ Diets } \\
\cline { 4 - 6 } & & & control & WBP & MBP \\
\hline Organic matter, \% DM & 87.25 & 87.11 & 92.68 & 92.75 & 92.43 \\
Crude protein, \% DM & 13.56 & 9.27 & 17.67 & 17.05 & 16.33 \\
Crude fibre, \% DM & 23.76 & 16.42 & 16.67 & 17.45 & 16.62 \\
NDF, \% DM & 51.09 & 47.57 & 37.17 & 39.86 & 38.56 \\
UFL, in DM & & & 0.85 & 0.85 & 0.85 \\
PDIN, g in DM & & & 105 & 97 & 96 \\
PDIE, g in DM $^{1}$ & & & 95 & 92 & 92 \\
\hline
\end{tabular}

${ }^{1}$ calculated according INRA, 1988 
change the particle size, which was in the range required for dairy cows. Feeding MBP or WBP slightly decreased mean DM intake and milk yield (Table 2), but the differences among treatments were not significant. Beet pulp, irrespective of the form, lowered slightly, but not significantly, the milk protein

Table 2. Dry matter intake, milk yield and composition and body condition of cows

\begin{tabular}{lcccc}
\hline \multirow{2}{*}{ Item } & \multicolumn{3}{c}{ Diets } & \multirow{2}{*}{ SEM $^{1}$} \\
\cline { 2 - 4 } DM intake, kg/day & control & WBP & MBP & 0.3 \\
Milk, kg/day & 21.1 & 20.9 & 20.0 & 0.6 \\
Fat, \% & 33.2 & 31.4 & 32.1 & 0.11 \\
Protein, \% & 4.55 & 4.74 & 4.33 & 0.04 \\
Urea, mg/L & 3.05 & 2.95 & 2.92 & 7.8 \\
BCS, point & 338 & 318 & 326 & \\
$\quad$ & & & 3.4 & 0.2 \\
start & 3.4 & 3.2 & $3.4^{\mathrm{a}}$ & 0.2 \\
\hline
\end{tabular}

${ }^{1}$ SEM - standard error of the means ${ }^{;}{ }^{\text {ab,c }}$ - means with different letters differ at $\mathrm{P}<0.05$

content but had no effect on other milk components. The body condition of cows fed the MBP diet changed significantly less than that of cows fed WBP. There were no differences among treatments for serum glucose, urea and $\beta$ hydroxybutyrate. However, feeding the MBP diet significantly lowered the serum NEFA concentration (Table 3).

Table 3. Serum blood parameters, $\mathrm{mM} / \mathrm{L}$ (means for 5 cows)

\begin{tabular}{|c|c|c|c|c|}
\hline \multirow{2}{*}{ Item } & \multicolumn{3}{|c|}{ Diets } & \multirow{2}{*}{$\mathrm{SEM}^{1}$} \\
\hline & control & WBP & MBP & \\
\hline \multicolumn{5}{|l|}{ At start of trial } \\
\hline glucose & 2.8 & 2.6 & 2.7 & 0.1 \\
\hline N-urea & 6.8 & 6.3 & 5.1 & 0.3 \\
\hline NEFA & 0.10 & 0.08 & 0.12 & 0.03 \\
\hline$\beta$-hydroxybutyrate & 0.39 & 0.50 & 0.49 & 0.05 \\
\hline \multicolumn{5}{|l|}{ At end of trial } \\
\hline glucose & 2.8 & 2.5 & 2.6 & 0.1 \\
\hline $\mathrm{N}$-urea & 4.7 & 5.6 & 4.5 & 0.3 \\
\hline NEFA & $0.28^{\mathrm{a}}$ & $0.20^{\mathrm{ab}}$ & $0.15^{b}$ & 0.02 \\
\hline$\beta$-hydroxybutyrate & 0.81 & 0.77 & 0.71 & 0.04 \\
\hline
\end{tabular}

${ }^{1}$ SEM - standard error of the means; ${ }^{a, b, c}$ - means with different letters differ at $\mathrm{P}<0.05$

\section{DISCUSSION}

Although an inclusion of $10 \%$ (on DM basis) of MBP or WBP into a diet caused a certain decrease in protein and increase in NDF contents, it had no 
significant effect on DM intake and performance of cows when studied during 6 weeks of the early lactation period. It is possible that replacing part of a starchy concentrate mixture by beet pulp positively affected rumen fermentation. Pectins, being the main energy component of beet pulp, are more digestible in the rumen than cellulose but, on the other hand, they are not as acidogenic as cereal starch (Van Soest, 1994). Cows fed MBP diets, compared with WBP, had a better energy status, confirmed by serum NEFA and body condition. It can be concluded that for a short period, beet pulp, particularly molassed dried, can replace part of a concentrate mixture in the diet without negative effect on the performance or energy status of cows in early lactation.

\section{REFERENCES}

AOAC, 1995. Official Methods of Analysis, Association of Official Analytical Chemists. $16^{\text {th }}$ Edition. Arlington, VA

INRA, 1989. Ruminant Nutrition: Recommended Allowances and Feed Tables. R. Jarrige (Editor). J. Libbey Eurotext, Paris

Nocek J.E., 1997. Bovine acidosis: implications on laminitis. J. Dairy Sci. 80, 1005-1028

SAS 1996. Release 6.12 for Windows. SAS Institute Inc., SAS Campus Drive, Cary, NC

Wildman E.E., Jones G.M., Wagner P.E., Boman R.L., Troutt Jr. H.F., Lesch T.N., 1982. A dairy cow body condition scoring system and its relationship to selected production characteristics. J. Dairy Sci. 65, 495-501

Van Soest P.J., 1994. Nutritional Ecology of the Ruminants. Cornell University Press. Ithaca, NY

\section{STRESZCZENIE}

\section{Wpływ częściowego zastąpienia mieszanki treściwej wysłodkami buraczanymi na wydajność i skład mleka krów we wczesnej laktacji}

W doświadczeniu określano wpływ zamiany części dawki mieszanki treściwej (2,25 kg s.m.) wysłodkami buraczanymi (2,5 kg s.m.): wilgotnymi kiszonymi (WBP) lub suchymi wysłodkami melasowanymi (MBP), produkowanymi według nowej technologii, polegającej na pokryciu granulatu olejem (Trident Feeds, BSO Polska). Krowy $(\mathrm{n}=30)$, średnio w 37 dniu laktacji, przydzielono metodą analogów do 3 grup żywieniowych (kontrolna, dawka z udziałem WBP, dawka z udziałem MBP) i żywiono indywidualnie, systemem TMR. Bez względu na rodzaj wysłodków, zamiana części mieszanki treściwej wysłodkami nieznacznie zmniejszyła zawartość białka oraz zwiększyła zawartość NDF w dawce, nie miała jednak istotnego wpływu na pobranie paszy, wydajność i skład mleka. Zastosowanie wysłodków melasowanych nie miało również ujemnego wpływu na kondycję krów, co stwierdzono przy skarmianiu wysłodków mokrych. Uzyskane wyniki wskazują na możliwość częściowego zastapienia mieszanki treściwej wysłodkami buraczanymi, zwłaszcza suchymi melasowanymi, w dawkach dla krów we wczesnym okresie laktacji. 